\title{
Katarzyna Płoszaj
}

ORCID: 0000-0003-1282-3293

Uniwersytet Wrocławski

https://doi.org/10.19195/1733-5779.38.12

\section{Nauka o literaturze w kontekście teorii Siegfrieda Schmidta}

Słowa kluczowe: nauka o literaturze, badania literackie, konstruktywizm, profesjonalizacja, empiryczna weryfikacja, interdyscyplinarność, przydatność

Keywords: scientific studies of literature, literary studies, constructivism, professionalization, empirical verification, interdisciplinarity, usefulness

Abstrakt: Profesjonalizacja, empiryczna weryfikacja, interdyscyplinarność i przydatność takie oto cztery imperatywy zostaną przedstawione w niniejszym artykule jako filary teorii stworzonej przez Siegfrieda Schmidta (zwanej teorią tekstów). Koncepcja, o której tutaj mowa, skoncentrowana jest wokół nauki o (szeroko pojętej) literaturze z perspektywy paradygmatu konstruktywistycznego, a prezentowane zgodnie z nią postulaty nabierają szczególnego znaczenia w kontekście prowadzenia pożytecznej działalności naukowej z zakresu badań literackich.

\section{Science of literature in the context of Siegfried Schmidt's theory}

Abstract: Professionalization, empirical verification, interdisciplinarity and usefulness -those four imperatives will be presented in this article as pillars of the theory (also known as text theory) devised by Siegfried Schmidt. This concept is concentrated around (broadly understood) literary studies viewed from the perspective of a constructivist paradigm, and the postulates presented within the concept's framework gain a special meaning while performing beneficial scientific activity in the area of literary studies.

\section{Literatura (nie) mówi sama za siebie}

Jeśli opuścimy nawias widniejący w tytule wprowadzenia do niniejszego artykułu ${ }^{1}$, otrzymamy hasło, pod którym Siegfried Schmidt — w publikacji (opartej na manuskrypcie wykładu, wygłoszonego podczas konferencji naukowej w Augsbur-

${ }^{1}$ Obszerniejsze omówienie tego, o czym mowa w tym artykule, znaleźć można w książce K. Płoszaj, Projektowanie treści w wymiarze communication design, Wrocław-Kraków 2021. 
gu w 1991 roku) Literaturoznawstwo jako projekt interdyscyplinarny ${ }^{2}$ — otwiera dyskusję na temat nauki o literaturze jako dyscypliny naukowej. Taka dyscyplina naukowa powinna służyć nie tyle „konserwowaniu dzieł literackich” (dbaniu o to, żeby wybrane dzieła nie straciły na wartości), ile społeczeństwu, to znaczy dostarczać odpowiedzi pozwalających (lepiej) zrozumieć, jak działa ten system funkcyjny (systemu społecznego), dzięki któremu literatura nie wychodzi z obiegu. Idąc tym tropem, na najbliższych stronach zreferowane zostaną poczynione przez Schmidta obserwacje i założenia, a ich prezentacja przybierze tutaj postać parafraz i cytatów pochodzących z wyżej wspomnianego artykułu z 1991 roku.

\subsection{Chwytliwa charakterystyka współczesnego społeczeństwa}

Prezentację rozważań Siegfrieda Schmidta dotyczących kondycji i przyszłości nauki o literaturze (w omawianym tu artykule z 1991 roku) rozpocząć trzeba od „chwytliwej charakterystyki współczesnego społeczeństwa”, czyli od tego, od czego należy zacząć, gdy rozpatruje się literaturoznawstwo jako - działający na zasadach programu komunikacji ,nauka” — system funkcyjny systemu społecznego. W tym celu trzeba przywołać stworzony przez Schmidta opis społeczeństwa, uwzględniający zarówno stan teraźniejszy (który choć przypadł na koniec ubiegłego stulecia, to jeszcze nie zdążył się zdezaktualizować), jak i procesy, które do niego doprowadziły.

W stosownych badaniach panuje dziś daleko idący konsensus co do tego, że sensowne jest opisywanie powstania europejskiego społeczeństwa jako przejścia od stanowo-feudalnej do funkcjonalno-zdyferencjonowanej formy organizacji. Ta transformacja, zapoczątkowana w XVIII stuleciu, jest znakiem rozpoznawczym rozwoju niezależnych systemów społecznych, które koncentrują się na wypełnianiu specyficznych, społecznie relewantnych zadań, jak na przykład produkcja towarów, produkcja kształcenia czy też produkcja prawdy. Jako zdyferencjonowane systemy, które w ramach ich nieuniknionej interakcji tworzą „społeczeństwo sieci”, systemy społeczne osiągają w drodze samoorganizacji pewną autonomię, przede wszystkim za sprawą wykształcenia specyficznych systemów komunikacji oraz za pośrednictwem zinstytucjonalizowanych ról społecznych (takich jak rola nauczyciela/przedsiębiorcy/naukowca/polityka). [...] Z takiej perspektywy obserwacyjnej [tu: z perspektywy zewnątrzsystemowej — K.P.] otrzymujemy koncept „literatura”, należący do takiego obszaru referencji, którego wykładnikiem nie jest zasób (kanonicznych) dzieł literackich, lecz są nim społeczne operacje — prymarnie komunikacje zachodzące na okoliczność fenomenów, tematyzowanych w komunikacjach jako fenomeny literackie. O literackości oraz literackiej randze tych fenomenów nie decydują zaś wyizolowany tekst i jego pozornie obiektywne cechy, lecz „komunikacyjne losy” literackich tekstów w systemie literatury: literatura nie mówi sama za siebie! ${ }^{4}$.

${ }^{2}$ Na potrzeby niniejszego opracowania dokonano własnego przekładu wybranych fragmentów artykułu Literaturwissenschaft als interdisziplinäres Vorhaben. Przy czym zaznaczyć należy, że w celu oddania sensu wywodu Schmidta nie trzymano się kurczowo dosłownego tłumaczenia, lecz pozwolono sobie na luźny przekład — tak, żeby dość precyzyjnie przybliżyć to, o czym mowa $\mathrm{w}$ oryginalnym wydaniu.

3 S. Schmidt, Literaturwissenschaft als Interdisziplinäres Vorhaben, Siegen 1991, s. 5.

${ }^{4}$ Ibidem, s. 6. 
Takie zaś zapatrywanie na literaturę jest o tyle funkcjonalne, że pozwala na wyciągnięcie pewnych wniosków, na podstawie których można postulować uwzględnienie realiów zarówno w teoretycznych rozważaniach, jak i w praktyce.

\subsection{Cztery imperatywy jako podwaliny teorii tekstów}

Po ustaleniu punktu wyjścia obranego przez Schmidta na okoliczność rozprawiania o naukowej eksploracji tekstów (w tym: literackich) nie pozostaje nic innego, jak tylko przejść do ukazania pewnych postulatów, które leżą u podłoża stworzonej przez tego naukowca koncepcji, mieszczącej się w obszarze nauki o (szeroko pojętej) literaturze jako niezależnej dyscypliny naukowej. Jakkolwiek obszernie można by rozwodzić się o podwalinach teorii Schmidta, w tym miejscu wyłożone zostaną one w postaci czterech imperatywów: profesjonalizacji, empirycznej weryfikacji, interdyscyplinarności oraz przydatności.

\section{Nauka o literaturze w obliczu czterech imperatywów}

\subsection{Imperatyw profesjonalizacji}

Profesjonalizacja ujęta została przez Schmidta — na polu nauki — jako wykształcenie i wyspecjalizowanie się specyficznego języka komunikacji, nadającego się do tworzenia teoretycznego instrumentarium. Kwestią kluczową jest tutaj (za)stosowanie znormalizowanego języka fachowego w celu wyjaśnienia fachowych pojęć w sposób zrozumiały (przy założeniu, że przyzwoicie wyeksplikowane pojęcia pozwalają fachowcom na właściwe ich zrozumienie, a dla reszty zainteresowanych są one zrozumiałe z grubsza). Kwestią krytyczną jest zaś „nastawienie na rozwiązywanie problemów (a nie na »napuszanie się«)" ${ }^{\prime 5}$. Za takim nastawieniem przemawia nie obstawanie przy tym, co się wie, lecz dążenie do poszerzania horyzontów na drodze wykorzystania znormalizowanych języków fachowych do konsensualnego (s)formułowania nauczalnej i wyuczalnej wiedzy. W tej materii zasadnicza zdaje się następująca kwestia: „Czy nie do tego powinny dążyć literaturoznawcze nauki i badania, żeby pomagać w uzyskaniu takiej wiedzy?"6. Pozytywna odpowiedź na to pytanie nie zamyka jednak kwestii, lecz pociąga za sobą kolejne pytania: po pierwsze, do czego taka wiedza może się przydać, a po drugie, na czym powinna ona bazować? W tym miejscu wystarczą na nie dwie krótkie odpowiedzi. Odpowiedź na pierwsze pytanie brzmi: do eksplorowania, a na drugie: na eksplorowaniu.

\subsection{Imperatyw empirycznej weryfikacji}

Prowadzenie badań wymaga podstawy teoretycznej, złożonej z prawidłowości będących niczym innym jak rezultatem obserwacji poczynionych przez obser-

\footnotetext{
5 Ibidem, s. 17

${ }^{6}$ Ibidem.
} 
watorów zewnątrzsystemowych. Stosując tę uniwersalną prawidłowość w sferze nauki o literaturze, otrzymujemy literaturoznawcze badania prowadzone przez literaturoznawców. Nie skupiają się oni na interpretacji badanych tekstów, lecz zajmują się ich właściwościami oraz zasadami, na których odbywają się recepcja i interpretacja tych tekstów (a interesujące są obserwacje dotyczące zarówno generalnie wszelakich tekstów, jak i poszczególnych przypadków).

W związku z tym do newralgicznych kwestii zajmowania się nauką o literaturze zaliczyć należy imperatyw empirycznej weryfikacji. Budowanie ,bazy literaturoznawczej wiedzy" zgodnie z tym imperatywem jest nota bene o tyle zasadne, że predysponuje do tego, aby taka wiedza stała się komunikacyjnie funkcjonalna. Funkcjonalność tej wiedzy spełnia zaś społeczne oczekiwania, które zostały ujęte przez Schmidta następująco:

Oczekiwania społeczeństwa wobec nauki o literaturze [...] ukierunkowane są na komunikacyjnie absorbowalną wiedzę, a nie na fantazje „pięknoduchów” bądź opowieści o osobistych wzruszeniach. „Komunikacyjnie absorbowalna wiedza” w systemie nauki oznacza empirycznie weryfikowalną (jako że uzyskaną sensowymi metodami) wiedzę o genezie, strukturze i intermedialności literackich fenomenów w ujęciu sensu largo (dotyczy to więc nie tylko tradycyjnych tekstów literackich); o strukturach, funkcjach, działaniach i instytucjach komunikacji o literackich fenomenach; o genezie, status quo i dynamice „ról działania” w systemie literackim; o produkcji, pośredniczeniu, recepcji i przetwarzaniu literackich fenomenów; w końcu również oznacza ona empirycznie weryfikowalną wiedzę o powstaniu i działaniu konwencji w systemie literackim, a także o genezie i oddziaływaniu procesów tworzenia (się) kanonów w systemie medialnym ${ }^{7}$.

\subsection{Imperatyw interdyscyplinarności}

W powyższych dwóch podpunktach podniesiono węzłowe kwestie dotyczące naukowych eksploracji. Teraz przyszedł czas na przedostatni z prezentowanych tu imperatywów, który uznaje się za strategiczny w obliczu takiego oto postulatu:

Nauka o literaturze, ograniczająca samą siebie [...] do formatu wyizolowanej hermeneutyki lub do doświadczeń transcendentalnych [...], nie byłaby zdolna do wykrzesania z siebie wystarczających kompetencji i kompleksowości, pozwalających na to, żeby z powodzeniem zająć się obszarami problemowymi [mieszczącymi się w zakresie literaturoznawstwa - K.P.] ${ }^{8}$.

Powodzenie w tej materii zdeterminowane jest wszak umiejętnym wykorzystywaniem możliwości, które można tworzyć, trudniąc się działalnością naukową. Literaturoznawstwo musi zatem spełniać kryteria naukowości, żeby mogło korzystać z tych możliwości, które można stworzyć w ramach nauki o literaturze. Konkludując: zakłada się, że nauka o literaturze należy do systemu nauki, a otwartość na tę systemowość jest koniecznym warunkiem rozwijania tej dyscypliny naukowej. Przy czym zważyć należy tutaj na następującą refleksję:

\footnotetext{
7 Ibidem, s. $17-18$.

8 Ibidem, s. 18.
} 
wskazówek o nieuniknionej interdyscyplinarności bynajmniej nie powinno się traktować jako apelu do otworzenia [na polu nauki - K.P.] „,sklepu wielobranżowego" [pod szyldem „literaturoznawczy miszmasz" - K.P.] albo jako wezwania do naukowej dobrotliwości. [...] Interdyscyplinarność nie znosi granic poszczególnych dyscyplin [naukowych - K.P.]; literaturoznawcy nadal pracują jako literaturoznawcy. Interdyscyplinarność oznacza raczej [po pierwsze - K.P.] formułowanie własnych problemów w taki sposób, aby reprezentanci innych dyscyplin mogli je w ogóle zrozumieć, oraz [po drugie - K.P.] takie eksplikowanie zoperacjonalizowanych propozycji rozwiązań problemów, żeby procedury rozwiązań zapożyczone z innych dziedzin mogły zostać sensownie sprawdzone i wypróbowane pod względem tego, czy są (bądź też mogą stać się) trafne. Że tak rozumiana interdyscyplinarność jest niezwykle wymagająca, wie każdy, kto trudnił się takimi badaniami: eksplicytne tworzenie teorii, [odpowiednia - K.P.] metodologia i fachowy język są przy tym nieodzowne?.

Reasumując: oczywiste jest to, że każda z dyscyplin ma swoje granice, a interdyscyplinarne podejście do zagadnienia nie podważa tych granic, lecz umożliwia przepływ informacji między dyscyplinami. Taki przepływ zaś stanowi kwestię zasadniczą z przyczyny, o której Schmidt mówi następująco: „Interakcje systemowe w systemie nauki oraz między systemem nauki a innymi systemami [funkcyjnymi — przyp. K.P.] — od ekonomii po politykę — są w każdym funkcjonującym społeczeństwie de facto zawsze w ruchu"10. Można jednak udawać, że się tego nie widzi, a „w najlepszym wypadku można pozostać na to ślepym"11. Wystarczy jednak spojrzeć z perspektywy obserwatora trzeciego stopnia, aby zobaczyć, że

literaturoznawstwo operuje „strukturalnie interdyscyplinarnie”, tak jak wszystkie inne nauki społeczne. Stąd też interdyscyplinarność powinna być wykorzystywana jako zbawienna szansa rozwoju. Innymi słowy: literaturoznawstwo powinno świadomie i strategicznie stać się tym, czym półświadomie i półgębkiem — z konieczności już jest: „interdyscyplinarnie operowalną” nauką społeczną $^{12}$.

\subsection{Imperatyw przydatności}

Do imperatywów: profesjonalizacji, empirycznej weryfikacji i interdyscyplinarności w tym punkcie dołącza czwarty: imperatyw przydatności, dla którego za obowiązujące przyjmuje się następujące założenie: wiedza przydatna jest o tyle, o ile pozwala coś zrozumieć. Zgodnie z tym twierdzeniem wiedza o literaturze jest przydatna o tyle, o ile pozwala zrozumieć ,literackie fenomeny” (literarische Phänomene). Czynienie wyjaśnień w sprawie tych fenomenów można zatem ustanowić priorytetem dla literaturoznawców respektujących imperatyw przydatności. Za ustanowieniem zaś takiego priorytetu przemawiają przytoczone poniżej konstatacje.
9 Ibidem, s. 11.
10 Ibidem, s. 10
11 Ibidem.
12 Ibidem. 
Poleca się pożegnanie z przestarzałym pojęciem literatury, z oczekiwaniem wypielęgnowanego pisania jako wartości samej w sobie, z polityczno-kulturowym sentymentalizmem, który Intelekt i Pieniądz wciąż uważa za ekwiwalent Boga i Diabła ${ }^{13}$.

Zamiast tego Schmidt, jako specjalista od teorii tekstów, skłania do rozważenia pewnej taktyki suponowanej przez ,specjalistę od wszystkiego - Bazona Brocka"14, którą reklamuje pod pojęciem „subwersywnej afirmacji” (subversive Affirmation). Powiązanie tej taktyki ze strategią „sprytnej manipulacji” Schmidt wyjaśnia następująco. Otóż, w ramach proponowanej/promowanej strategii wychodzi się od takich oto obserwacji,

które poczynić można nie tylko w systemach gospodarki i reklamy: nasze społeczeństwo płaci tylko wtedy, kiedy oferowane jest coś, na co jest zapotrzebowanie (na marginesie mówi się także o potrzebach intelektualnych/duchowych); a wielu oferentów walczy o deficytowe dobro: „uważność”

Przy czym, jeśli ma się ambicje sprzedania danej oferty komunikacyjnej, nie można poprzestać na zadowoleniu się zagospodarowaniem uwagi danej publiczności. Wszak szkopuł polega na tym, żeby nie tylko przykuć uwagę, lecz także zainteresować. Dlatego też zastosowanie znajduje tutaj pojęcie uważności ${ }^{16}$, które pociąga za sobą wyższy stopień wtajemniczenia. Bądź co bądź „obecnie zyskują na tym tylko sprytni"17. A jakkolwiek cynicznie to brzmi, to uprzytomniająca jest kolejna wypowiedź Schmidta:

Kto twierdzi, że nasze społeczeństwo zorientowane jest wyłącznie na materialne dobra, a nasza polityka naukowa nastawiona jest tylko na „maksymalną bezpośrednią możliwość spożytkowania” i „technokratyczne podnoszenie wydajności”, uprawia, świadomie bądź nieświadomie, daleką od empirii propagandę ${ }^{18}$.

Rzut zaś oka na dostępne oferty medialne uzmysławia nam to, co zaobserwował Schmidt. Mianowicie:

— istnieje niemałe zapotrzebowanie na czynienie doświadczeń z tekstami literackimi oraz na zbieranie doświadczeń, które zaczerpnąć można wprost (lub poniekąd) z tych tekstów;

- pojawia się potrzeba poddawania się (samo)krytyce oraz dokonywania wglądu we własne i obce sposoby produkowania sensu;

— zauważalny jest popyt na analizowanie procesów wartościowania czy też przewartościowywania ${ }^{19}$. W związku z tym

13 Ibidem, s. 20.

14 Ibidem.

15 Ibidem.

16 Zob. M. Fleischer, Estetyka tu i tam i jej wpływ na komunikację, Łódź 2010; E. Langer, Aktives denken. Wie wir geistig auf der Höhe bleiben, Reinbek 1991.

17 S. Schmidt, op. cit., s. 20.

18 Ibidem.

19 Zob. ibidem, s. 20. 
nauka o literaturze winna być zobowiązana do zaoferowania czegoś, co temu zapotrzebowaniu wyjdzie naprzeciw (albo je stworzy?), wychodząc od tego i opierając się na tym, że społeczeństwo wciąż „funduje sobie" literaturę oraz literaturoznawstwo jako system [funkcyjny systemu społecznego - przyp. K.P. $]^{20}$.

\section{Stąd też}

nauka o literaturze również musi przyciągać (uwagę) tą zorientowaną na popyt ofertą. Potrzebuje zatem reklamy i stosownego wizerunku medialnego [...]. Nie jest to bynajmniej — żeby uniknąć nieporozumień — orędowanie za tym, żeby bezwarunkowo rzucać się na szyję kapitalizmowi z jego rynkowymi i reklamowymi strategiami. Zaleca się tu raczej sprytniejsze obchodzenie się z pewnymi strategiami w celach (literaturoznawczonaukowych) ${ }^{21}$.

Jak widać, postulaty Schmidta są tyleż rozsądne, co kontrowersyjne. Przy czym ich kontrowersyjność bynajmniej nie osłabia ich siły przebicia, lecz ją umacnia. Nawiasem mówiąc: jeśli nie uprawia się klakierstwa, lecz naukę, to trzeba liczyć się z wywoływaniem takich kontrowersji. Stąd też Schmidt, podsumowując swój wykład - mimo świadomości tego, że „,dobra rada kłuje w uszy”22 — nie wypiera się swoich twierdzeń, lecz je motywuje. Koniec końców, owo wystąpienie potraktować można jako swego rodzaju manifest niosący pewne przesłanie, które towarzyszy tworzeniu również tego opracowania. W tym miejscu nie pozostaje zatem nic innego, jak tylko zademonstrować, w jaki sposób Schmidt zwieńczył swoje konstatacje.

Literaturoznawstwo ma przyszłość, ponieważ może wyzwolić niebywały potencjał transformacji. Mianowicie: świadome (samo)doskonalenie literaturoznawstwa jako nauki społecznej; wykorzystanie potencjału, który tkwi w poważnej interdyscyplinarności; intermedialna kontekstualizacja wszystkich literackich fenomenów; i w końcu sensowna empiryzacja w ramach elaborowanych teorii. W obliczu tego potencjału, który stanowi olbrzymie wyzwanie dla literaturoznawczyń i literaturoznawców, tylko uzależniony od interpretacji mizantrop może „wylewać żale”. Literaturoznawstwo jest projektem z przyszłością dla wszystkich, którzy kochają intelektualne wyzwania ${ }^{23}$.

Przy czym Schmidt uwrażliwia na to, że w wymiarze naukowym nie można pozwolić sobie na miłość bezwarunkową, takowa bowiem potrafi oślepić. Stąd też „,kto jako literaturoznawca albo literaturoznawczyni chce literaturze pomóc, winien ją kochać, ale nie może jej ubóstwiać" ${ }^{24}$. Zwłaszcza zatem w przypadku tak uwodzącej dyscypliny jak nauka o literaturze konieczne jest stosowne ustosunkowanie się do wybranego obiektu badawczego. W ramach badania (literackich) tekstów wybrane teksty powinny być traktowane jako obiekty badawcze - ni mniej, ni więcej. A w ramach zajmowania się literaturoznawstwem winno się

20 Ibidem, s. 20-21.

21 Ibidem, s. 21.

22 To japońskie powiedzenie w przemówieniu Schmidta przybrało skądinąd takie oto brzmienie: „Ich bin sicher, manchem von Ihnen klingt dies garstig in den Ohren” (S. Schmidt, op. cit., s. 21).

23 Ibidem, s. 22.

${ }^{24}$ Ibidem, s. 21. 
postrzegać je nie tylko jako naukę, lecz także jako obiekt komunikacji, któremu należy „zrobić taką reklamę”, aby zachęciła w pierwszej kolejności do zainteresowania tą dyscypliną, a w dalszej - do tego, by dać jej szansę na uwolnienie literaturoznawczego potencjału. W ten wizerunkowy kontekst literaturoznawstwa wpisuje się zaś takie oto dictum: literatura ,jest produktem. Powinniśmy więc — jako jego pełna zapału agencja reklamowa — nadać temu produktowi taką osobowość, która zaintryguje nawet w społeczeństwie mediów masowych" ${ }^{25}$. Konkludując: postuluje się tutaj — dla dobra sprawy, to jest zamiarem zadbania o dogodne korzystanie z uroków piśmiennictwa - rozpatrywanie literatury (między innymi naukowej) w kategoriach produktu, a nauki o literaturze (tudzież o czymkolwiek innym) - w kontekście sektora usługowego. Wychodzi się tu bowiem z założenia, że instytucje naukowe pojmować należy jako instytucje usługowe nastawione na zaspokajanie potrzeby eksploracji, a zatem zapewniające możliwość stawiania (mniej lub bardziej) stosownych pytań oraz szukania i znajdowania stosownych odpowiedzi. W kwestii produkowania odpowiedzi newralgiczny aspekt stanowi oczywiście pytanie, czy jest na nie popyt. W przypadku literaturoznawstwa szkopuł polega zatem na tym, żeby odpowiedzi, których ta instytucja usługowa dostarcza, były odpowiedzią na popyt bądź też aby odpowiedzi te były na tyle absorbujące, żeby — przez odpowiednie ich rozreklamowanie — popyt na nie został wywołany. Przy czym wychodzi się tu z założenia, że uzasadniony popyt jest (po)dyktowany potrzebami. W żadnym wypadku zatem nie chodzi o wyprodukowanie niepotrzebnych nowości, lecz o produkowanie rzeczy, pytań oraz odpowiedzi, które są czy stają się potrzebne i użyteczne. Instytucje naukowe należą zatem do instytucji usługowych o tyle użytecznych, o ile służą wiedzą i czynieniem wyjaśnień oraz dawaniem w pierwszej kolejności takich odpowiedzi, na które jest zapotrzebowanie, a w dalszej — takich, które są potrzebne ze względu na wagę danych pytań. $Z$ literaturoznawczych instytucji naukowych może więc być nie lada pożytek — pod warunkiem że zajmują się one wyjaśnieniem tego, jak działają literatura oraz rynek literacki, a przy tym służą wiedzą zarówno specjalistyczną, jak i powszechną. Rozpatrywanie nauki o literaturze w wymiarze reklamowym i wizerunkowym to kwestia przetrwania.

\section{Teoretyczne i praktyczne znaczenie imperatywów}

Profesjonalizacja, empiryczna weryfikacja, interdyscyplinarność i przydatność - takie oto cztery imperatywy należy uznać za relewantne w zakresie nauki o literaturze z tego względu, że trzymanie się ich pozwala, po pierwsze, na tworzenie transparentnych konceptualizacji służących wyjaśnieniu wybranych zagadnień, po drugie, na wykorzystanie potencjału, jaki niosą z sobą porządnie przygotowane eksploracje, i po trzecie, na prowadzenie pożytecznej działalności

25 Ibidem. 
naukowej. Jest to o tyle newralgiczne, że jeśli nie ma pożytku z tego, co robimy, to trwonimy kapitał kognitywno-emocjonalny, który jest wystarczająco cenny, aby warto było inwestować go w przedsięwzięcia mające przyszłość, czyli otwierające na nowe możliwości i perspektywy dalszego rozwoju w ramach obranego kierunku. W kontekście nauki o literaturze nabiera to szczególnego znaczenia przez wzgląd na to, czego możemy się dowiedzieć dzięki prowadzeniu badań w zakresie tej dyscypliny. Literatura umożliwia między innymi wgląd w rozmaite wyobrażenia o rzeczywistości — w postaci interpretacji realiów czy wizji rodem z science fiction. Eksplorowanie, identyfikowanie zaś i analizowanie ujętych w literaturze obrazów świata pozwala wyciągnąć na światło dzienne repertuar koncepcji, które są wytworem naszej imaginacji czy odzwierciedleniem naszych realiów. Owe koncepty, niezależnie od tego, co jest ich źródłem, demonstrują kody komunikacyjne oraz wyobrażenia determinujące ramy i kształt nie tylko rzeczywistości w wymiarze literackim, lecz także tej, w której żyjemy. Literaturę postrzegać zatem należy jako kopalnię informacji, z której możemy czerpać na drodze rozpatrywania jej z perspektywy badawczej, czyli przez stosowanie w praktyce teorii takich jak teoria Siegfrieda Schmidta.

\section{Bibliografia}

Fleischer M., Estetyka tu i tam i jej wpływ na komunikację, Łódź 2010.

Konstruktywizm w badaniach literackich. Antologia, red. E. Kuźma, A. Skrendo, J. Madejski, Kraków 2006.

Langer E., Aktives denken. Wie wir geistig auf der Höhe bleiben, Reinbek 1991.

Płoszaj K., Projektowanie treści w wymiarze communication design, Wrocław-Kraków 2021.

Schmidt S., Diskurs und Literatursystem. Konstruktivistische Alternativen zu diskurstheoretischen Alternativen, [w:] Diskurstheorien und Literaturwissenschaft, red. J. Fohrmann, H. Müller, Frankfurt am Main 1998, s. 134-160.

Schmidt S., Grundriß der Empirischen Literaturwis — senschaft: mit einem Nachwort zur Taschenbuchausgabe, Frankfurt am Main 1991.

Schmidt S., Interpretation eine Geschichte mit Ende, [w]: Vom Umgang mit Literatur und Literaturgeschichte: Positionen und Perspektiven nach der Theoriedebatte, red. L. Danneberg, F. Vollhardt, Stuttgart 1992.

Schmidt S., Język, pismo, rzecz i prawda, [w:] Konstruktywizm w badaniach literackich. Antologia, red. E. Kuźma, A. Skrendo, J. Madejski, Kraków 2006, s. 233-249.

Schmidt S., Konstruktywizm, teoria systemowa i literaturoznawstwo empiryczne. Kilka uwag na temat aktualnej debaty, [w:] Konstruktywizm w badaniach literackich. Antologia, red. E. Kuźma, A. Skrendo, J. Madejski, Kraków 2006, s. 251-286.

Schmidt S., Literaturwissenschaft als Interdisziplinäres Vorhaben, Siegen 1991, www.uni-siegen. de/infme/start_ifm/downloads/lumis_schriften/lumis_normal/nr_30-91.

Schmidt S., Od tekstu do systemu. Zarys konstruktywistycznego (empirycznego) modelu nauki o literaturze, [w:] Konstruktywizm w badaniach literackich. Antologia, red. E. Kuźma, A. Skrendo, J. Madejski, Kraków 2006, s. 199-219. 